\section{Den Politiske Forbruger}

Mads P. Sorensen: Den politiske forbruger. Hans Reitzels Forlag, 2004, 136 s.,

I bogen Den Politiske Forbruger sætter idehistoriker Mads P. Sørensen sig for at beskrive og diskutere "Den politiske forbruger". Bogen bygger for Sørensens mangeårige forskning indenfor området, som bl.a. er udmøntet $\mathrm{i}$ en $\mathrm{PhD}$-afhandling. Bogen består af tre kapitler. Det første kapitel indeholder en beskrivelse af det politiske forbrugs historie, præsentation af forskellige definitioner af politisk forbrug, det politiske forbrugs empiriske omfang og hvordan det kan sammenlignes med andre typer af forbrugere - fx etiske eller økologiske forbrugere. Der redegøres for den eksisterende forskning (dog overvejende begrænset til den danske forskning) hvoraf det fremgår, at definitioner, operationaliseringer og bestemmelse af omfang er vidt forskellige og ofte vanskelige at sammenligne. Kapitlet indeholder også fyldige beskrivelser af en række eksempler på politisk forbrug, hvilket giver et godt indblik i, hvordan politisk forbrug praktiseres og udmøntet på forskellige måder.

I kapitel 2 diskuteres det, med afsæt $i$ teorier om liberale samfund (fra John Locke over Adam Smith og Bernard de Mandeville til Friedrich Hayek og Milton Friedman) og økonomiteori, hvordan og om man overhovedet kan forstå politisk forbrug fra disse perspektiver samt om politisk forbrug er en god ide; om det er normativt ønskværdigt. To hovedkonklusioner der drages er, for det første, at det, fra et liberalt perspektiv, er vanskeligt at forstå, hvorfor individer overhovedet handler som politiske forbrugere, idet politiske forbrugere sammenblander økonomi og politik, samt det private og det offentlige, som er adskilte størrelser i liberal teori. For det andet, at det kan være direkte skadeligt at foretage en sådan sammenblanding $i$ forhold til et mål om velstandsstigning. En interessant pointe er desuden, at der peges på inkonsistenser i liberal teori, idet den politiske forbruger på den ene side kan ses som legitim i kraft af den enkeltes ret til frit valg og dermed frit valg til at agere som politisk forbruger, men samtidig, på den anden side, er illegitim i kraft af at den politiske forbruger sammenblander den politiske og økonomiske sfære, og dermed begrænser optimal velstandsproduktion.

I bogens tredje kapitel introduceres to andre markedsaktører, som sætter adskillelsen mellem politik og økonomi under pres, nemlig "etiske investorer" og "politiske virksomheder". Også her er der tale om fyldige beskrivelser af forskellige eksempler, som er nyttige til en mere substantiel forståelse af fænomenerne. Det konkluderes, at etiske investeringer, politiske virksomheder og politiske forbrugere kan ses som en kritik af en liberalistisk samfundsmodel. Kapitlet afsluttes med en opsum- 
mering af den liberale kritik af den politiske forbruger: For det første at det politiske forbrugs konsekvenser ikke er entydigt gode, men kan have negative konsekvenser, fx i form af ikke-optimal velstandsstigning i bl.a. udviklingslandene. For det andet er der en række (liberal) demokratiske problemer knyttet til politisk forbrug. Blandt andet fremhæver Sørensen ulighed som et problem, idet ikke alle har de fornødne økonomiske ressourcer til at handle som politiske forbrugere. Derudover sker der en markedsmæssiggørelse af politikken, når det politiske system fører politik via markedet. Sørensen foreslår en sondring mellem politisk forbrug "nedefra" hvor forbrugeren har ikkeøkonomiske motiver bag sit forbrug. Og politisk forbrug "oppefra", som bruges til at beskrive den situation, hvor det politiske system fører politik via markedet. Ifølge Sørensen er politisk forbrug "nedefra" legitimt set fra et liberalistisk perspektiv, jf. individets ret til frit valg. Omvendt er politisk forbrug "oppefra" illegitimt: dels fordi det er en ansvarsforflygtigelse fra det politiske systems side, dels fordi forbrugere forestilles at indtage en borgerrolle. I den sidste del af kapitel 3 genoptages diskussionen om politisk forbrug kan forsvares normativt. Med afsæt i sociologen Ulrich Beck's teori om risiko-samfund og sub-politik diskuteres det, hvordan liberale tænkeres normative legitimering af adskillelsen mellem politik og økonomi, nemlig velstandsstigning, udfordres af nye problemer i risikosamfundet; selve velstandsstigningen og frisættelsen af økonomien, har en række negative sideeffekter, som er samtidens påtrængende problemer. Afslutningsvis diskuterer Sørensen om det, set i lyset af nye risici, "er en god idé at blive ved med at betragte markedet som værende apolitisk" (s. 115). Problemet, ifølge Sørensen, er, at det nationale politiske system ikke har kapaciteten til at løse påtrængende globale problemer og eksisterende transnationale sammenslutninger er ikke tilstrækkeligt forpligtende. I en sådan situation kan globalt orienterede politiske forbrugere $\mathrm{i}$ en overgangsfase være en alternativ reguleringsmekanisme til et globalt orienteret erhvervsliv - "alle manglerne til trods" (s. 116).

Der er ingen tvivl om at bogen Den Politiske Forbruger er uomgængelig for personer, som interesserer sig for politisk forbrug. Bogen er skrevet i et lettilgængeligt sprog og forfatterens mål om at lave en "alment tilgængelig indføring $i$ og diskussion af emnet den politiske forbruger" (s. 8) er i høj grad lykkedes. Således er bogen ikke kun tilgængelig og anbefalelsesværdig for forsker-fællesskabet, men også for mennesker, som er alment interesseret i politik og samfund, og som er særligt interesserede $i$ at få indsigt i centrale temaer og diskussioner ud i politisk forbrug.

Derudover kan flere ting fremhæves som særligt udmærkede ved Sørensens bog - meritter, som 
samtidig giver anledning til at rejse nye spørgsmål. For det første er det unikt inden for (den politologiske) litteratur om politisk forbrug, at bogen rejser spørgsmålet om politisk forbrug overhovedet er en god ide og at der foretages en teoretisk diskussion heraf. Og dette gøres ydermere på en meget overbevisende facon. Dette spørgsmål - hvad den normative kritik/legitimering af politisk forbrug er - bør inspirere studier udover de idéhistoriske, herunder politologiske og sociologiske studier, som oftest fokuserer på det politiske forbrugs empiriske omfang og på (teoretisk) forståelse af fænomenet. Sørensens valg af liberalistisk og økonomisk teori er både oplagt og ikke-oplagt. Det er oplagt, fordi ideerne udgør grundlæggende værdier i vestlige samfund. I den udstrækning, man er enig $i$ en liberal tankegang, giver bogen derfor værdifuldt input til at diskutere politisk forbrug. Derudover er det overbevisende og relevant at bruge risiko-samfundsperspektivet til at kritisere grundantagelsen (at målet er velstand) i liberalistisk teori. Men i og med at politisk forbrug langt hen af vejen er illegitim ud fra en liberalistisk position, bliver man som læser nysgerrig efter alternative normative betragtninger, som kan legitimere politisk forbrug. Sørensen rejser dette spørgsmål, og det er overbevisende, når den politiske forbruger begrundes med afsæt $i$ risiko samfundet. Men Sørensens eget alternativ om, at den politiske forbruger er en over- gangsfigur, indtil det politiske system er beredt til at optage sig opgaven, er mindre overbevisende, endsige teoretisk funderet. Kunne man forestille sig andre teoribygninger, der kunne danne et legitimt normativt grundlag for politisk forbrug? - eksempelvis et diskursivt demokrati perspektiv a la John Dryzek's i Deliberately Democracy and Beyond. Liberals, Critics, Contestations fra 2000 - hvor det politiske forbrug kan tolkes som en kritik af en liberal økonomisk diskurs. En inkludering af perspektiver, der ser politisk forbrug som en legitim figur ville give læseren et mere balanceret grundlag til at vurdere om politisk forbrug er en god ide. Dette er dog en ret stor opgave, hvorfor det mere skal ses som en stafet til videre forskning, end som en egentlig kritik af Sørensens bidrag.

En anden pointe, der skal fremhæves, er, at Sørensen på overbevisende vis påpeger et dilemma i liberalistisk teori: mellem den enkeltes ret til at handle som politisk forbruger, og at denne ret bliver problematisk når liberal teori samtidig antager en adskillelse mellem politik og økonomi. Derfor kan det undre, at Sørensen ikke fremhæver dette mere og diskuterer hvilke konsekvenser, det kan have for liberal teori (som dog måske mere er temaet for en anden bog!).

For det tredje: Det er frugtbart for den eksisterende litteratur om politisk forbrug, at Sørensen understreger, at en vurdering af omfanget af politisk forbrug er afhængig af, 
"bvad man ønsker at få svar på: Er det, hvor stor politisk betydning politisk forbrug har? Eller er det, hvor stor betydning politisk forbrug har på markedet?" (s. 51). Sørensen kalder dette henholdsvis et "politologisk perspektiv" (hvor politisk forbrug er et ret udbredt fænomen, fordi mange bruger politisk forbrug som en politisk deltagelseskanal) og et "markedsperspektiv" (hvor politisk forbrug er et begrænset fænomen, idet markedsandelen er lille). Denne pointe bør hjælpe til at nuancere diskussionerne mellem politologer og forbrugs/markedsforskere om udbredelsen af politisk forbrug.

Sørensens bog giver også anledning til at rejse spørgsmål, hvor jeg her skal fokusere på to ting. For det første: Selv om Sørensen ikke lægger sig fast på én definition af politisk forbrug, men i stedet gør en dyd ud af at diskutere forskellige definitioner, antages det, at politisk forbrug er rettet mod "andet" eller "andre" end egeninteresser, og denne pointe er afsættet for den liberale kritik. Men det er ikke indlysende, at politisk forbrug per definition er rettet mod en kollektiv værdi og "andet" eller "andre". Politisk forbrug kan sagtens indeholde realiseringen af egeninteresse, hvor individet erkender, at egeninteressen bedst realiseres ved at være orienteret mod kollektive mål. Hvis politisk forbrug tolkes langs disse linjer vil det som minimum nuancere dilemmaerne i liberal teori, idet det også peger på et dilemma mellem antagelsen om egeninteresse på den ene side, og adskillelsen af økonomi og politik på den anden side (og dermed ikke kun som et dilemma ift. individets ret til at vælge, jf. ovenfor). Det mere generelle spørgsmål er, om en sådan bredere, og efterhånden ret accepteret, definition af politisk forbrug har andre implikationer for den liberale kritik?

Den anden kritiske bemærkning fortsætter i samme spor: Sørensen antager, at den politiske forbruger og politiske virksomheder sammenblander politik og økonomi, når de handler politisk på markedet. På det empiriske niveau er dette formentlig en rimelig antagelse. Men dermed er det ikke nødvendigvis tilfældet på det teoretiske niveau. Sørensen redegør selv for positioner, der mener, at virksomheder handler som politiske virksomheder, fordi det er økonomisk rentabelt og dermed holdes egeninteresseperspektivet intakt; politisk virksomheder er et strategisk redskab. Sørensen udvikler ikke dette teoretisk, men man kan substantivere et sådant perspektiv ved en Luhmanniansk systemteoretisk tilgang, idet det politiske og økonomiske system fortsat vil være adskilte sociale systemer, selv om individer eller virksomheder overskrider grænsen i empirisk forstand. Spørgsmålet er altså, om det er rimeligt at konkludere, at politisk forbrug som empirisk fænomen er en kritik af liberal teori andet end på det rent holdningsmæssige niveau. Teoretisk set er der ikke nødvendig- 
vis tale om en sammenblanding af økonomi og politik.

Bogens merit er således ikke kun de ting som denne anmeldelse fremhævede indledningsvist, men også at bogen rejser nye diskussionspunkter og spørgsmål.

Mette Tobiasen

\section{At tanke, det underledes}

Gilles Deleure: Foucault, oversat og indledt af Karsten Gam Nielsen og Kim Su Rasmussen, Det lille Forlag, 2004, 160 s., $225 \mathrm{kr}$.

Endnu en af Deleuzes mange monografier har set dagens lys $i$ en fint fungerende dansk oversættelse fra Det lille Forlag, nemlig denne originale læsers bog om Michel Foucault fra 1986 (i 2003 udkom Proust-bogen fra 1964, anmeldt i Slagmark nr. 40.).

Deleuze arbejder i sin Foucaultbog med på projekt 'tænk anderledes', som i sporet fra Nietzsche og Heidegger bryder med antagelsen af universel og a-historisk konciperet konstituering af menneskelig virkelighed. Til dette spor hører også en problematisering af grammatikken og fremgangsmåden implicerer, at der arbejdes med neologismer eller udvidelser af det semantiske spillerum for allerede kendte ord - eller at der ses helt bort fra grammatikken, idet man - som Foucault - udskiller et 'udsagnets område', hvor "enhver realitet er manifest", og hvor "kun det tæller, der er blevet sagt, her, i dette øjeblik, med disse huller og disse udeladelser" (s. 23).

Det er Deleuzes pointe, at det er i forsøget på at tænke 'det udenfor', dvs. det, der gør modstand ( $f_{x}$ det sociale felt), at Foucault bl.a. når til en ny forståelse af, hvorledes det anderledes underledes $i$ en 'magtens mikrofysik', og hvorledes det sagte og synlige kun kan spille i kraft af en igangværende, men usynlig funktions usigelighed.

Et andet omdrejningspunkt er en vis pragmatik. I forbindelse med Foucaults nybrydende indsats i bogen Overagning og straf skriver Deleuze, at det her "handler om spørgsmålet: bvad skal gores?" (s. 49). Svaret på dette kantiansk klingende spørgsmål ligger angiveligt $\mathrm{i}$ bestræbelsen på en nyorientering af praksis, og længere fremme i sin bog samler Deleuze Foucaults filosofi under betegnelsen "mangfoldighedens pragmatik" (s. 98). Med henblik på en sådan pragmatik bryder Foucault først og fremmest med fænomenologiens intentionalitetsbegreb overfor hvilket han synes at foretrække en variant af Kant i konstruktionen af sit begreb om viden. Deleuze skriver: "At tale og at se - eller snarere udsagnene og synlighederne - er rene elementer, aprioriske betingelser, ifølge hvilke alle ideerne i en given tid formuleres og alle adfærdsformerne manifesteres. Denne søgen efter betingelser udgør en slags neokantianisme hos Foucault. Der er dog væsentlige forskelle i forhold til Kant: betingelserne 